\title{
Literature Review on Benefits, Opportunities, Challenges, Prospects of Online Teaching in Higher Education
}

\author{
Hegde Lata Narayan ${ }^{1}$ \& Shailashri V. T. ${ }^{2}$ \\ ${ }^{1}$ Research Scholar, College of Management \& Commerce, Srinivas University, Mangalore, \\ India. \\ OrcidID:0000-0003-3326-3715, E-mail: lathah69@gmail.com \\ ${ }^{2}$ Research Professor, College of Management and Commerce, Srinivas University, \\ Mangalore, India. \\ OrcidID:0000-0002-1684-238X, E-mail: shailashrivt@gmail.com
}

Subject Area: Management.

Type of the Paper: Review based Research Agenda.

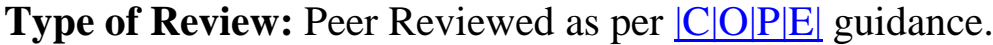

Indexed In: OpenAIRE.

DOI: https://doi.org/10.5281/zenodo.5799382

Google Scholar Citation: IJAEML

How to Cite this Paper:

Hegde, Lata Narayan, \& Shailashri, V. T., (2021). Literature Review on Benefits, Opportunities, Challenges, Prospects of Online Teaching in Higher Education. International Journal of Applied Engineering and Management Letters (IJAEML), 5(2), 232-245. DOI: https://doi.org/10.5281/zenodo.5799382

International Journal of Applied Engineering and Management Letters (IJAEML)

A Refereed International Journal of Srinivas University, India.

Crossref DOI : https://doi.org/10.47992/IJAEML.2581.7000.0115

(C) With Authors.

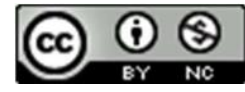

This work is licensed under a Creative Commons Attribution-Non-Commercial 4.0 International License subject to proper citation to the publication source of the work.

Disclaimer: The scholarly papers as reviewed and published by the Srinivas Publications (S.P.), India are the views and opinions of their respective authors and are not the views or opinions of the S.P. The S.P. disclaims of any harm or loss caused due to the published content to any party. 


\title{
Literature Review on Benefits, Opportunities, Challenges, Prospects of Online Teaching in Higher Education
}

\author{
Hegde Lata Narayan ${ }^{1} \&$ Shailashri V. T. ${ }^{2}$ \\ ${ }^{1}$ Research Scholar, College of Management \& Commerce, Srinivas University, Mangalore, \\ India. \\ OrcidID:0000-0003-3326-3715, E-mail: lathah69@gmail.com \\ ${ }^{2}$ Research Professor, College of Management and Commerce, Srinivas University, \\ Mangalore, India. \\ OrcidID:0000-0002-1684-238X, E-mail: shailashrivt@gmail.com
}

\begin{abstract}
Purpose: An analysis of literature review on benefits, opportunities, challenges, prospects of online teaching in higher education gives an insight into various factors leading to the effective implementation of online teaching in higher education institution. An honest attempt is made for enabling the teachers to understand these factors for adopting online teaching in higher education institutions.
\end{abstract}

Design/Methodology/Approach: This study is a qualitative literature review, which is based on secondary data. This data is collected from various websites, journals, research papers, articles, several surveys, and reports.

Findings/Results: Based on detailed analysis of literature review, assisted in finding out research gap and prospective research proposal which will help in the formulation of the future research study in the area of online teaching in higher education.

Originality/Value: This paper analyses and identifies the research gap after a detailed analysis of the literature review. Based on the research gap, specifies the research proposal for further study.

Paper Type: A literature review on benefits, opportunities, challenges, prospects of online teaching in Higher Education.

Keywords: Online teaching, Roles and practices, Teaching environments, Instruction technology, Factors identification, SWOC analysis.

\section{INTRODUCTION :}

With the fast development and utilization of modern communication and information tools, students adopting to partly/fully online classes, there is a transition from the traditional classroom to online teaching. The scope of higher education in providing diverse opportunities in the field of various programs to the students, there is a rise in the demand for online teaching. For satisfying a large student population, online teaching provides an exciting prospect in making classes more accessible to the students. To address this challenge there is a need to train and develop the faculties in developing and teaching online instruction accessible to a large number of students. Necessity is the mother of invention. Hence higher education should optimally utilize its existing resources in transforming formal education to online education with the use of the latest instruction technology. For the advancement of a teaching career, universities should ask their faculties for adopting fully/partly online classes. For achieving success in online instruction, it is necessary to motivate teachers to face various challenges and threats while undergoing changing roles in an online environment. The various factors should be identified which directly or indirectly affect online teaching, to overcome the various problems and threats in order to achieve teachers' success in online teaching platforms. Science and technology are advancing at exponential speeds and are going to make it possible within a decade to solve some of the grand challenges of humanity such as disease, hunger, energy, and education. It will take a global effort, and that is why scientists, entrepreneurs, and teachers need to play a role.

The Literature Review attempts to cover the following:

a) The university faculty were highly satisfied with Google Classroom, Google Hangouts, and LMS for course organization and assessment [2]. 
b) Higher learning institutions determined to provide diverse educational opportunities, there is increased demand for online learning [9].

c) There is a need for a leadership support team to work in collaboration with the office of information and communication technology at the University for online or blended learning programs. [16].

d) Higher educational institutions should adopt a Competency-Based Credit system that allows students to earn competency in various programs [25].

e) The higher education institutions to be on par with today's Tech-savvy generation should concentrate on strategies to differentiate themselves in the field of online education competitive market [45].

f) The pandemic has changed the global education system from a traditional classroom to elearning [50].

\section{RESEARCH OBJECTIVE AND METHODOLOGY :}

The ultimate purpose of this paper is to recognize the research gap for adopting online teaching by faculties in higher education. The main objectives are:

- To ascertain the roles and practices of teachers in an online teaching environment

- To review the literature related to challenges, benefits, opportunities, and prospects of online teaching

- To identify the Research gap based on a literature study

- To explore the prospective research proposal for further study

In this literature review paper, adoption of instruction technology in higher education by teachers is reviewed and studied. This analysis of literature involves, review of an adequate number of research papers and scholarly articles published in Journals, websites, magazines, and newspapers. It is based on secondary data and tries to find the research gap.

\section{REVIEW OF RESEARCH LITERATURE :}

With the growth of computer-based instruction there is a drift towards E-learning along with classroom learning and experiential learning [1]. Several factors were found to make online teaching more effective such as time management, application of various online platforms such as LMS, Asynchronous e-learning, course design presentation, blended courses [2]-[6]. There is a need to focus on factors affecting teachers' motivation, social roles, interpersonal roles of teachers, adopting partially or fully online classes [7]-[9]. To encourage the blending of technology and learning, professional development of teachers, listening to teachers' voices, leadership support team, and community-based interaction and feedback become essential [14]-[17]. Academic improvement for achieving desirable results, the academic department should include teacher committee for the integration of information by faculty and students [21]. Higher educational institutions should adopt a competency-based credit system that allows students to earn competency in various programs with less interaction with the teachers and is an ideal model for 'learn-while-earn' [25].

Barriers to effective online classes can be resolved by appropriate networking and exchanges of teaching experiences with colleagues or specialists, professional development for teachers, and training for learners by higher educational institutions [27]-[29]. For preparing students industryready, learners should adopt the latest skill technologies such as simulations, virtual interfaces, collaboration with industry, government, and universities for increasing quantity and quality of online classes [32]-[34]. For the development of third world countries, teachers should be empowered with more autonomy in innovations, evaluation of curriculum, methods of teaching [36].

In order to face challenges of pandemic c like Covid-19, there is a need to critically evaluate E-learning technology such as social and cognitive presence while designing digital learning activities, collaboration among the various deans, administration, and heads of higher educational institutions [37], [39]-[42]. The pandemic situations all over the world have made it essential for adopting a global education system by utilizing user-friendly tools such as ICT and higher educational institutions should focus on today's tech-savvy generations' various needs for successful implementation of teaching and learning for all the stakeholders [45]-[50]. 
Table 1: The list of scholarly publications related to online teaching and learning.

\begin{tabular}{|c|c|c|}
\hline $\begin{array}{l}\text { S. } \\
\text { No. }\end{array}$ & Focus & Reference \\
\hline 1. & $\begin{array}{l}\text { Developments in communications, computer-based instruction, and pupil } \\
\text { learning systems have extended the opportunities in online instruction and } \\
\text { student learning. There is a drift towards redefining specialized instructor } \\
\text { and learner parts in a more constructivist mode. }\end{array}$ & [1] \\
\hline 2. & $\begin{array}{l}\text { The research findings exposed that students are content with university } \\
\text { faculty who approved definite online platforms for assessment choices, } \\
\text { grading methods, online technical assistance, and more. It also showed that } \\
\text { members were highly satisfied with Google Classroom, Google Hangouts, } \\
\text { and LMS (learning management system) for course organization and } \\
\text { assessments. }\end{array}$ & [2] \\
\hline 3. & $\begin{array}{l}\text { Several decisions were found to make online teaching more effective, } \\
\text { adequate time must be allotted for each course, faculty should design and } \\
\text { watch each course for time management, students should be motivated to } \\
\text { assume their responsibilities of learning styles, students having proficiency } \\
\text { in writing, and reading performs better in e-Learning. }\end{array}$ & [3] \\
\hline 4. & $\begin{array}{l}\text { Asynchronous styles of communication were favored by students, to move } \\
\text { at their own pace and students with previous training in computers were } \\
\text { more contented with online courses. Continuous research is required to } \\
\text { share the characteristics, outcomes, and institutional features of the course } \\
\text { plan. }\end{array}$ & [4] \\
\hline 5. & $\begin{array}{l}\text { Further research in course design presentation would enable academicians } \\
\text { to have better alternatives in e-Learning. The quality of course workload } \\
\text { and materials should be improved by upgrading the communication and } \\
\text { information technology. }\end{array}$ & [5] \\
\hline 6. & $\begin{array}{l}\text { The study showed a comparison in the effectiveness of traditional, online, } \\
\text { and blended teaching. A positive response was received for recently } \\
\text { introduced blended courses for satisfying learning, traditional classroom } \\
\text { teaching was preferred for creating a positive attitude to the subject matter. }\end{array}$ & [6] \\
\hline 7. & $\begin{array}{l}\text { In online teaching, faculty satisfaction is considered an important factor. } \\
\text { Research results show that three factors affect the satisfaction of faculty in } \\
\text { online teaching, student-related, instructor-related, and institution-related } \\
\text { factors. }\end{array}$ & [7] \\
\hline 8. & $\begin{array}{l}\text { It focuses on the social roles of teachers and students in online teaching } \\
\text { such as the development of the community, the formation of an online } \\
\text { presence. It endorses future research on personal, social, and interpersonal } \\
\text { traits influencing the learning of subject material in online environment. }\end{array}$ & [8] \\
\hline 9. & $\begin{array}{l}\text { With higher learning institutions determined to provide diverse educational } \\
\text { opportunities, there is increased demand for online learning as a means of } \\
\text { providing more access to a large number of students. Hence university } \\
\text { instructors while designing teaching careers may have to adopt partially or } \\
\text { fully online classes. }\end{array}$ & [9] \\
\hline 10. & $\begin{array}{l}\text { The use of digital technologies can increase the quality of learning if it is } \\
\text { used as a communicative tool to help the collaboration of knowledge. To } \\
\text { prepare students as innovative knowledge developers it is important to } \\
\text { recognize the blending of formal and informal learning strategies in higher } \\
\text { education. }\end{array}$ & [10] \\
\hline 11. & $\begin{array}{l}\text { There is uncertainty relating to more consumption of time in preparation } \\
\text { and presentation in the case of online teaching for instructors. There is a } \\
\text { need to develop an inquisitive online learning system on par with traditional } \\
\text { classrooms. }\end{array}$ & [11] \\
\hline 12. & $\begin{array}{l}\text { To motivate, engage and challenge teachers using technology, pedagogical } \\
\text { practice, performance evaluation, curriculum development, and }\end{array}$ & [12] \\
\hline
\end{tabular}




\begin{tabular}{|c|c|c|}
\hline & $\begin{array}{l}\text { professional management META model suggesting mentoring, } \\
\text { engagement, technology, and assessment endorses content design and } \\
\text { sharing information. }\end{array}$ & \\
\hline 13. & $\begin{array}{l}\text { In order to fit every institution's evaluation needs of various online course } \\
\text { F2F applications, suitable rating scales and other methods of teaching } \\
\text { efficiency must be custom-made to the specific online or blended courses } \\
\text { of every institution. }\end{array}$ & [13] \\
\hline 14. & $\begin{array}{l}\text { To encourage the integration of learning and technology, professional } \\
\text { development plays a prominent role in preparing teachers to connect to } \\
\text { other learners in the international community. }\end{array}$ & [14] \\
\hline 15. & $\begin{array}{l}\text { The research found that listening to teachers' voices is important and in } \\
\text { order to achieve online teacher personas, a participatory role has to be } \\
\text { considered. Teachers' past experiences beliefs, assumptions towards } \\
\text { learning and teaching should be motivated to prepare teachers to teach } \\
\text { online. }\end{array}$ & [15] \\
\hline 16. & $\begin{array}{l}\text { The requirement of engaging diverse learners today, university programs } \\
\text { are made more convenient by the faculty members. There is a need for a } \\
\text { leadership support team to work in collaboration with the office of } \\
\text { information and communication technology at the university for online or } \\
\text { blended learning programs. }\end{array}$ & [16] \\
\hline 17. & $\begin{array}{l}\text { Online learning requires flexibility and willingness among the faculty and } \\
\text { students in trying new methods in pedagogy. To help learners to be } \\
\text { successful they should collaborate in the learning practice, community- } \\
\text { based interactions, and reaction to feedback. }\end{array}$ & [17] \\
\hline 18. & $\begin{array}{l}\text { The percentage of literate in the total population in India is improving due } \\
\text { to e-learning and e-commerce. Through appropriate planning and } \\
\text { investigation in e-learning, there will be an improvement in higher } \\
\text { education among women which will lead to the development of education } \\
\text { and growth of the nation. }\end{array}$ & [18] \\
\hline 19. & $\begin{array}{l}\text { In order to improve the students' learning skills, three factors knowledge, } \\
\text { skills, and perception of the faculty could affect their motivation. The use } \\
\text { of these factors encourages faculty to use online tools which improve their } \\
\text { quality of teaching in creating effective learning presentation for students. }\end{array}$ & [19] \\
\hline 20. & $\begin{array}{l}\text { Challenges linking learner support with campus resources and altering } \\
\text { teaching design to meet students' desire to gain knowledge. The teacher's } \\
\text { role in understanding the various components of a successful online } \\
\text { program can facilitate recommendations to instructors and improve online } \\
\text { learning to the students. }\end{array}$ & [20] \\
\hline 21. & $\begin{array}{l}\text { The role of e-learning in teaching and learning has been strongly established } \\
\text { due to easy communication and interaction with students in spite of some } \\
\text { challenges. Academic improvement in its standards can be achieved with } \\
\text { the availability of a rich environment for integration among students and } \\
\text { access to information by learners and faculty. }\end{array}$ & [21] \\
\hline 22. & $\begin{array}{l}\text { Two variables of teacher's presence in the college and its impact on } \\
\text { students' course satisfaction were studied. The result indicated that students } \\
\text { who loved teachers' presence relatively high in online classes were highly } \\
\text { satisfied in the college programs. }\end{array}$ & [22] \\
\hline 23. & $\begin{array}{l}\text { Faculty would be significantly influenced by Blended Learning, in case } \\
\text { adequate infrastructure, pedagogical and technological support, evaluation } \\
\text { data are adopted by an institution. }\end{array}$ & [23] \\
\hline 24. & $\begin{array}{l}\text { The learning process is made more individualized by including technology. } \\
\text { The use of technology along with traditional classroom dynamically } \\
\text { involve the learner as it assists in performing any activities and solving } \\
\text { problems with the help of a teacher. Blended learning acts as an efficient } \\
\text { learning process. }\end{array}$ & [24] \\
\hline
\end{tabular}

Hegde Lata Narayan, et al, (2021); www.srinivaspublication.com 


\begin{tabular}{|c|c|c|}
\hline 25. & $\begin{array}{l}\text { The higher educational institution should adopt a Competency-Based Credit } \\
\text { system that allows students to earn competency in various programs with } \\
\text { less interaction with the teachers and is an ideal model for 'learn-while- } \\
\text { earn' getting more practical knowledge in their area of interest. }\end{array}$ & [25] \\
\hline 26. & $\begin{array}{l}\text { There is a necessity to plan and enhance the curriculum on online courses } \\
\text { by higher education institutions for meeting learners' requirements. In order } \\
\text { to achieve desirable results, the academic department should include a } \\
\text { teacher committee for appraising and planning online courses frequently. }\end{array}$ & [26] \\
\hline 27. & $\begin{array}{l}\text { Studies about teachers' perceptions about the use of technology for online } \\
\text { classes and their experience about it are reflected in TAM (Technology } \\
\text { accepted model). Barriers to the effective presentation of online classes } \\
\text { technically assisted requirements, and enrolment of manageable online } \\
\text { classes are revealed in the research studies. }\end{array}$ & [27] \\
\hline 28. & $\begin{array}{l}\text { Factors such as attitudes, competence, methodology, technology, training, } \\
\text { time limit, and pedagogy will assist teachers in their conceptual structure } \\
\text { for e-readiness. Higher education institutions may succeed in implementing } \\
\text { e-Learning "without having to spend the cost, effort, and time" by } \\
\text { understanding these factors. }\end{array}$ & [28] \\
\hline 29. & $\begin{array}{l}\text { Difficulties faced by teachers in altering from traditional teaching to digital } \\
\text { learning, an alternative innovation of classroom teaching may be resolved } \\
\text { through exchanges of teaching experiences with colleagues or specialists to } \\
\text { improve classroom management and teaching styles. Appropriate } \\
\text { networking helps the teachers to achieve their goal of dispersing systematic } \\
\text { knowledge to learners. }\end{array}$ & [29] \\
\hline 30. & $\begin{array}{l}\text { Research findings relating to online learners, challenges were assessed such } \\
\text { as Instructors' issues, Learner issues, and content issues. To resolve these } \\
\text { challenges there is a need for professional development for teachers, } \\
\text { technical assistance for content development, and training for learners by } \\
\text { higher education institutions for implementing online teaching. }\end{array}$ & [30] \\
\hline 31. & $\begin{array}{l}\text { Apprehensions among teachers about their reputation as online faculty, } \\
\text { apparent hurdles to learners for success in online classes, and their } \\
\text { expectations about manageable class and adequate workload have been } \\
\text { divulged in the studies. }\end{array}$ & [31] \\
\hline 32. & $\begin{array}{l}\text { Studies have shown that learners improve their knowledge and } \\
\text { understanding by adopting the latest skill adoption technologies such as } \\
\text { simulations, interactivity, gaming, virtual interfaces, which will enhance } \\
\text { their experience through appropriate digital learning. }\end{array}$ & [32] \\
\hline 33. & $\begin{array}{l}\text { Bridging the gap in program curriculum is critical to making students } \\
\text { industry-ready, which can be achieved by making necessary alterations in } \\
\text { online education in collaboration with industry, government, and } \\
\text { universities. For providing more opportunities among rural youths in India, } \\
\text { courses should be drafted in various languages to enhance their social } \\
\text { talents. }\end{array}$ & [33] \\
\hline 34. & $\begin{array}{l}\text { There is a need for increasing the quantity and quality of contact in online } \\
\text { classes in the case of public administration and research methods classes as } \\
\text { students are appraised on the basis of grades. }\end{array}$ & {$[34]$} \\
\hline 35. & $\begin{array}{l}\text { In spite of various problems and prospects for instructors, administrators, } \\
\text { and designers in the online learning environment, there should be sharing } \\
\text { of experiences and information among the online instructors in shaping the } \\
\text { online learning environment for the } 21^{\text {st }} \text { century. }\end{array}$ & [35] \\
\hline 36. & $\begin{array}{l}\text { For continuous development of quantity and quality of faculty performance, } \\
\text { the Indian government has adopted NEP 2019, which empowers teachers } \\
\text { with more autonomy in innovations and evaluation of curriculum, methods } \\
\text { of teaching. }\end{array}$ & [36] \\
\hline
\end{tabular}




\begin{tabular}{|c|c|c|}
\hline 37. & $\begin{array}{l}\text { Due to the Covid-19 pandemic, higher education is facing grave challenges } \\
\text { worldwide. Crisis management requires to include social, facilitatory, and } \\
\text { cognitive presence while designing digital new learning activities. }\end{array}$ & [37] \\
\hline 38. & $\begin{array}{l}\text { Technical issues, lack of adequate training and development in conducting } \\
\text { online teaching to the faculties has become a hurdle for the successful } \\
\text { implementation of online classes. Therefore, replacement of traditional } \\
\text { classroom teaching is a challenge. }\end{array}$ & [38] \\
\hline 39. & $\begin{array}{l}\text { There is a need to avoid tensions and chaos during pandemics and disasters } \\
\text { such as Covid-19 by adequate evaluation of the pros and cons of digital } \\
\text { learning and teaching. There is a need for critical evaluation of E-learning } \\
\text { technology intensely to avoid tensions and fears while facing such a crisis. }\end{array}$ & [39] \\
\hline 40 . & $\begin{array}{l}\text { To face crises like the Covid-19 pandemic, higher educational institutions } \\
\text { should adopt workshops and training for all the faculty and students through } \\
\text { various available e-Learning solutions. There should be collaboration } \\
\text { among the various deans, administration, and heads of higher education } \\
\text { institutions for making education possible to all the students through } \\
\text { various e-learning platforms. }\end{array}$ & [40] \\
\hline 41. & $\begin{array}{l}\text { To guide online teaching to a new level so that students are benefitted, a } \\
\text { model consisting of modification, augmentation, substitution, and } \\
\text { redefinition of technology adoption in education should be used for e- } \\
\text { Learning. }\end{array}$ & [41] \\
\hline 42. & $\begin{array}{l}\text { Technology in education seems to be permanent due to the fear of a } \\
\text { pandemic, Covid-19 still continuing. E-Learning may become a normal } \\
\text { mode of education model. Hence there is a need for adopting the various } \\
\text { online methods of learning and teaching till the pandemic last and } \\
\text { traditional teaching resumes. }\end{array}$ & [42] \\
\hline 43. & $\begin{array}{l}\text { Studies show that the majority of teachers and students favor traditional } \\
\text { classroom teaching due to a lack of internet speed and other technical issues } \\
\text { while conducting online teaching and learning. For retention and } \\
\text { understanding of topics, personal interaction is required between faculty } \\
\text { and students. }\end{array}$ & [43] \\
\hline 44. & $\begin{array}{l}\text { A blended learning program is preferred over didactic online courses by } \\
\text { students. Since task value, goal settings, belief can be better grasped in } \\
\text { blended learning, which in fact is the future of the educational institution. }\end{array}$ & [44] \\
\hline 45. & $\begin{array}{l}\text { The higher education institutions to be on par with today's Tech-savvy } \\
\text { generation should concentrate on strategies to differentiate themselves in } \\
\text { the field of online education competitive market. }\end{array}$ & [45] \\
\hline 46. & $\begin{array}{l}\text { In order to meet the challenges of future learning and teaching system of } \\
\text { the world, Bhutan has to invest in ICT (information and communication } \\
\text { technology), the development of teachers, and effective pedagogy. User- } \\
\text { friendly tools are to be utilized for making e-Learning more effective and } \\
\text { creative. }\end{array}$ & [46] \\
\hline 47. & $\begin{array}{l}\text { Students have to depend on e-Learning due to fear of the Covid-19 } \\
\text { pandemic across the world, but rural areas in India lack an effective } \\
\text { broadband connection. This creates a challenge for learners for pursuing } \\
\text { their academic courses. }\end{array}$ & [47] \\
\hline 48. & $\begin{array}{l}\text { The pandemic situation all over the world has made it obligatory for } \\
\text { adopting digital learning for the education sector. Adequate infrastructure, } \\
\text { trained faculty, stable government policies, global access to the network has } \\
\text { to be pursued for the successful implementation of digital learning for all } \\
\text { the stakeholders of education. }\end{array}$ & [48] \\
\hline 49. & $\begin{array}{l}\text { In low-income countries like Ghana, investment in ICT has played a very } \\
\text { significant role in the successful application of e-Learning. There are } \\
\text { several barriers for e-Learning which are resolved with the incorporation of } \\
\text { ICT for enhancing online learning in Ghana. }\end{array}$ & [49] \\
\hline
\end{tabular}


50. $\quad$ The research found that teaching online is itself challenging to the teacher due to the perception of faculty about teaching online. The pandemic has changed the global education system from a traditional classroom to elearning.

\section{SUMMARY OF CURRENT STATUS :}

Since the conventional educational system is similar to brick and mortar system wherein students have face-to-face contact with the faculty undergoing programs from various colleges and universities. There is a need for satisfying next-generation education requirements who are tech-savvy by adopting online teaching and learning. Students are fond of digital instructions which have removed some of the major hurdles of classroom teaching such as transportation, cost, documentation, and accessibility. Application of training and development using pedagogy and technology in online teaching by the higher educational institutions has to be incorporated for effective implementation of online education to all the stakeholders.

\section{FACTORS IDENTIFIED FOR EFFECTIVE IMPLEMENTATION OF ONLINE TEACHING :}

Based on the study of the literature review, several extraneous factors responsible for adopting online teaching in educational institutions were identified. Google Classroom, Google Hangouts \& LMS for course assessment \& management [2], Digital technology used as a participatory communication tool to improve quality of learning experience [10], Leadership support team in collaboration with the office of information technology [16], Community based interaction, practice by faculty \& students collaboration [17], Higher educational institution should adopt Competency-Based Credit system [25], Academic department should include teacher committee for appraising and planning online courses [26], Alternative innovation of class teaching [29], Application of NEP 2019, Autonomy to teachers both in innovation in curriculum evaluation methods [36], The higher education institutions to be in par with today's Tech-savvy generation [45], ICT (Information \& communication technology) effective pedagogy to make online interaction effective [46], Integration of ICT in education [49].

\section{FACTORS IDENTIFIED}

Community based interaction

Leadership support team

ICT \& effective pedagogy

Application of NEP 2020

Alternative innovation of class teaching
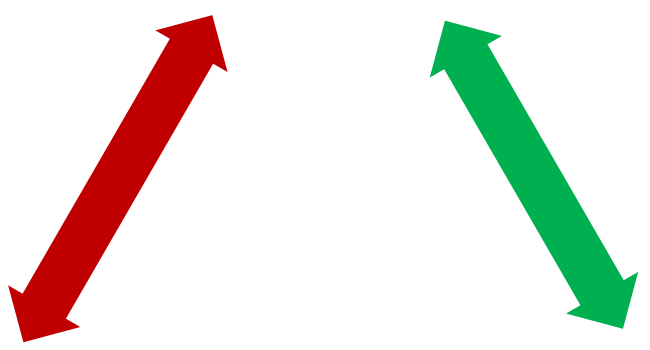

OPPORTUNITES

Additional courses

Raise in standard of living

Revisit recorded learning

Instruction technology

\section{CHALLENGES}

Resistance to change

No personal Interaction

Misuse of social platform

Demotivation

Fig. 1: Diagram representing Challenges, Opportunities \& Factors identified for Online Teaching. 


\section{NEW RELATED ISSUES :}

Owing to the pandemic, online learning and teaching have become the new norm in the field of education. It has become necessary due to the restriction of movement of human beings against the spread of the covid19 virus. In such a situation the prospect of online teaching should be evaluated and justified for the mutual benefit of teaching fraternity and learners. The benefits of imparting knowledge through online teaching in higher education should be explored so that the purpose of teaching and learning could be attained in a systematic manner.

\section{IDEAL SOLUTION :}

After slowing down of pandemic and restarting the economy in a new way, there arises the dilemma of whether offline classes are the only solution for imparting education. Whether online teaching should be adopted in certain fields of education where traditional teaching fails to achieve its mark. There is a need to identify who is going to reap the benefit of online teaching. Whether the focus group is the students, teachers, institutions, decision-makers, policymakers, and society. META model motivates teachers for content design and sharing information [12]. The ideal solution may include satisfying students all over the world irrespective of country, social, economic, cultural, linguistic, age, and gender by imparting high-quality education which is sustainable for a long period of time [25]. Adequate infrastructure, trained faculty, stable government policies have to be pursued [48], [51].

\section{RESEARCH GAP :}

Although modern technological developments introduced e-Learning in higher education, which has an impact on teachers' role in digital instruction. Challenges such as resistance from students and teachers to prefer a traditional system of learning since it lacks personal interaction, motivation to instructor and learners, irritation due to lack of basic infrastructure. Benefits such as teachers needn't be physically present, saving time and cost of traveling. They can prepare teaching material at their convenience and students too can get training and education at their place. Opportunities such as students can complete various interesting courses which are essential for their advancement of career. Teachers can enhance their earning by undertaking various assignments and projects for increasing their standard of living. In order to achieve sustainable development in India, there is a necessity to increase the quality and quantity of higher education institutions. Government colleges have their own challenges and threat such as inadequate facilities and infrastructure, low student enrolment rate, large vacancies in faculty, outmoded teaching methods, lack of funds, narrow domain, and teaching shop. Several factors affecting, directly and indirectly, teachers' roles and practices in adopting online teaching in higher education have been identified by various researchers. This paper proposes to identify more factors for the successful utilization of online teaching for teachers in higher education, especially in coastal Karnataka.

\section{RESEARCH PROPOSAL :}

After understanding the various opportunities embedded in this paper and after analyzing the literature review, the following proposal is proposed:

9.1 Title:

Prospects of online teaching in Management Education in Coastal Karnataka

9.2 Purpose:

Already several factors have been identified for helping higher education institutions to succeed in adopting online teaching. This study would throw light on various other requirements for implementing online teaching in higher education. Recently government colleges play a very prominent role in enhancing the quality and quantity of higher education in India. The main purpose of the study would be to trace out and identify various other direct and indirect factors essential for the successful implementation of online teaching in higher education especially with reference to Coastal Karnataka. Further, it will focus on undergraduate government commerce teachers in D.K. in adopting online teaching.

9.3 Research Objectives:

(1) To analyze the scope of online teaching

(2) To understand the system and constitution of higher education in India

(3) To explore the roles and practices of teachers in an online teaching environment

Hegde Lata Narayan, et al, (2021); www.srinivaspublication.com 
(4) To identify the factors responsible for online teaching in U.G programs

(5) To suggest the essential requirements for helping teachers achieve success in adopting online teaching

\section{SWOC ANALYSIS :}

This analysis lists out the strength, weakness, opportunities and Challenges [52] on application of online instruction in higher education institutions, as follows:

10.1 Strength:

$>$ Students across the world will get quality education

$>$ Accessibility of choice-based and competency-based system

$>$ Academicians could contact global students

$>$ Saving of time, cost, documentation

$>$ Examination system could be digitalized

$>$ Innovation in content design and pedagogy

$>$ Raise in the standard of living

$>$ Branding of popular educational programs

10.2 Weakness:

$>$ Huge investment in Information and Communication technology

$>$ Misuse of social media

$>$ Irritation due to lack of basic infrastructure

$>$ Overall development is not possible due to lack of personal contact

$>$ Students have to compete globally

$>$ Misunderstanding of Government policies and programs

$>$ Lack of Motivation among the students

10.3 Opportunities:

$>$ Global demand for various Job oriented course

$>$ High-quality education irrespective of country, age, gender, economic, cultural, and social background.

$>$ Intellectual needs of students are satisfied

$>$ Accessibility with low cost and time

$>$ Ideal pedagogies could be optimally utilized

10.4 Challenges:

$>$ Third world countries have financial and economic constraints

$>$ Lack of global acceptance of online courses

$>$ Soft skills could not be effectively implemented

$>$ Confusion relating to exam and evaluation

$>$ Personality development is adversely affected

\section{SUGGESTIONS :}

After analyzing the prospects of online teaching in higher education, a research gap is identified for further study. In order to narrow down the research gap, more study has to be undertaken on the various beneficiaries of focus groups so that after the pandemic online teaching could be adjudged as the best alternative innovation of class teaching.

\section{LIMITATIONS:}

The research proposal is bound by time. The study makes assumptions based on available secondary data. The scope of the study is limited to coastal Karnataka and only to the government colleges. This proposal is also subject to the limitation of accessing data from the various focus groups.

\section{CONCLUSION :}

Digital teaching will bring plenty of career opportunities in the field of higher education. Implementation of NEP 2020 will undergo vast changes in the Indian education system. Due to the applicability of principles of equity \& accessibility by the central and state government, there are increasing efforts to increase and develop government colleges. There is a necessity to relook at quality education for accomplishing India's future requirements. This paper makes a sincere attempt to 
identify factors for the successful implementation of online teaching in higher education institutions. Hoping for further research to follow in facing challenges and boosting higher education in India.

\section{REFERENCES :}

[1] Renee Wallace, (1996). The Challenges of Effective Online Instruction and Student Learning. Teachers Journal, 32(1), 1-18.

Google Scholar ${ }^{7}$

\section{CrossRef/DOI $x^{7}$}

[2] Norah Almusharraf, Shabir Khahro, (2000). Students Satisfaction with Online Learning Experiences during the COVID-19 Pandemic. International Journal of emerging technologies in Learning, 15(21), 246-267.

Google Scholar $\not 7$

CrossRef/DOIX

[3] Barbara Slater Stern, (2004). A Comparison of Online and Face-To-Face Instruction in an Undergraduate Foundations of American Education Course. Online Journal, 24(1), 126-131.

Google Scholar X

CrossRef/DOIX

[4] Mary K. Tallent-Runnels, Julie A. Thomas, William Y. Lan, Sandi Cooper, Terence C. Ahern, Shana M. Shaw, and Xiaoming Liu, (2006). Teaching Courses Online: A Review of the Research. Review of Educational Research (journal), 76(1), 93-135.

Google Scholar 7 CrossRef/DOIX

[5] Omamerhi Ebojoh, Hongjiang Xu, (2007). Effectiveness of Online Learning Program: A Case Study of a Higher Education Institution. Journal issues in information systems, 8(1), 160-166. Google Scholar $x^{7} \quad$ CrossRef/DOI $\chi^{7}$

[6] Agnes Goz Pearcy, B.A., M.S, (2009). Finding the Perfect Blend: A Comparative Study of Online, Face-To-Face, and Blended Instruction. Education and Information Technologies, 36(2), 1-129. Google Scholar X CrossRef/DOI $\chi^{\top}$

[7] Doris U. Bolliger \& Oksana Wasilik, (2009). Factors influencing faculty satisfaction with online teaching and learning in higher education. Online Journal, 16(3), 103-116.

Google Scholar $\chi^{7} \quad$ CrossRef/DOI ${ }^{7}$

[8] Raven M. Wallace, (2010). Online Learning in Higher Education: a review of research on interactions among teachers and students. Communication \& Information online journal, 3(2), 241-280.

$\underline{\text { Google Scholar }} \quad \underline{\text { CrossRef/DOIX }}$

[9] Jared Keengwe, Terry T. Kidd, (2010). Towards Best Practices in Online Learning and Teaching in Higher Education. MERLOT Journal of Online Learning and Teaching, 6(2), 533-541.

Google Scholar X

CrossRef/DOI 7

[10] Kwok-Wing Lai, (2011). Digital technology and the culture of teaching and learning in higher education. Australasian Journal of Educational Technology, 27(8), 1263-1275.

Google Scholar $x^{7} \quad$ CrossRef/DOI $x^{\top}$

[11] Mischelle Taylor Stone, Suzanne Perumean-Chaney, (2011). The Benefits of Online Teaching for Traditional Classroom Pedagogy: A Case Study for Improving Face-to-Face Instruction. MERLOT Journal of Online Learning and Teaching, 7(3), 393-400.

Google Scholar $\chi^{\top} \quad \underline{\text { CrossRef/DOI } \chi^{\top}}$

[12] Dittmar, Eileen; McCracken, (2012). Promoting Continuous Quality Improvement in Online Teaching: The META Model. Journal of Asynchronous Learning Networks, 16(2), 163-175. Google Scholar $x^{\top} \quad$ CrossRef/DOI $x^{\top}$

[13] Ronald A. Berk, (2013). Face-to-Face versus Online Course Evaluations: A "Consumer's Guide" to Seven Strategies. MERLOT Journal of Online Learning and Teaching, 9(1), 345-362. Google Scholar $X^{\top} \quad \underline{\text { CrossRef/DOIX }}$

[14] Barr, Betty A.; Miller, Sonya F, (2013). Higher Education: The Online Teaching and Learning Experience. Online Submission, 2(1), 1-23.

Google Scholar $x^{\top} \quad$ CrossRef/DOI $x^{\top}$

Hegde Lata Narayan, et al, (2021); www.srinivaspublication.com 
[15] Evrim Baran, Ana-Paula Correia \& Ann Thompson, (2013). Tracing Successful Online Teaching in Higher Education: Voices of Exemplary Online Teachers. Teachers college Record, 65(2), 17 28.

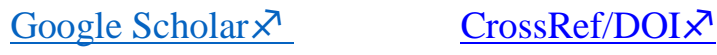

[16] Hilliard, Ann Toler, (2015). Global Blended Learning Practices for Teaching and Learning, Leadership and Professional Development. Journal of International Education Research, 11(3), 179-188. Google Scholar 7

CrossRef/DOIX

[17] Andrade, Maureen Snow, (2015). Teaching Online: A Theory-Based Approach to Student Success. Journal of Education and Training Studies, 3(5), 1-9. Google Scholar $x^{\prime}$ CrossRef/DOI $X^{7}$

[18] Arun Gaikwad, Vrishali Surndra Randhir, (2015). E-Learning in India: Wheel of Change, ijeeee, $6(1), 40-45$.

Google Scholar $X^{7}$

\section{CrossRef/DOIX}

[19] Siti Nurul Mahfuzah Mohamada, Mohd Azran Mohd Sallehb, Sazilah Salam, (2015). Factors Affecting Lecturers Motivation in Using Online Teaching Tools. Procedia - social and Behavioural sciences, 5(2), 1778- 1784.

Google Scholar $x^{7} \quad$ CrossRef/DOIX

[20] Lavonne Fedynich, Karen Sue Bradley, Jack Bradley, (2015). Graduate students' perceptions of online learning. Research in Higher Education Journal. 27(6), 1-13.

Google Scholar $X^{7} \quad$ CrossRef/DOI $X^{7}$

[21] Valentina Arkorful and Nelly Abaidoo, (2015). The role of e-learning, advantages, and disadvantages of its adoption in higher education. International Journal of Instructional Technology and Distance Learning, 12(2), 33-81. Google Scholar $x^{7} \quad$ CrossRef/DOIX

[22] Khalid, Mohd N. M.; Quick, Don, (2016). Teaching Presence Influencing Online Students' Course Satisfaction at an Institution of Higher Education. International Education Studies, 9(3), 62-70.
Google Scholar 7
CrossRef/DOIX

[23] Wendy W. Porter, Charles R. Graham, (2016). Institutional drivers and barriers to faculty adoption of blended learning in higher education. British Journal of Educational Technology, 2016, 47(4), 748-762.

\section{Google Scholar $\nearrow^{7} \quad$ CrossRef/DOI $x^{\top}$}

[24] Maria Josephine, (2016). Effectiveness of a Blended Learning Programme on Academic Achievement in Teaching of Physical Science among Student Teachers of Puducherry. Research papers shodhganga@Inflibnet. 9(3), 253-256.

Google Scholar $x^{7} \quad$ CrossRef/DOIX

[25] Aithal,P. S. \&. Shubhrajyotsna Aithal, (2016). Impact of Online Education on Higher Education. International Journal of Engineering Research and Modern Education (IJERME), 1(1), 225-235. Google Scholar $\chi^{7}$

CrossRef/DOIX

[26] Raghu N. Singh and David C. Hurley, (2017). The Effectiveness of Teaching-Learning Process in Online Education as Perceived by University Faculty and Instructional Technology Professionals. Journal of Teaching and Learning with Technology, 6(1), 65-75.

\section{Google Scholar $x^{\top} \quad$ CrossRef/DOIX}

[27] Wingo, N. P., Ivankova, N. V., \& Moss, J. A. (2017). Faculty perceptions about teaching online: exploring the literature using the technology acceptance model as an Organizing Framework. Online Learning, 21(1), 15-35.

Google Scholar X

CrossRef/DOIX

[28] Thanh Thi Ngoc Phan, and Ly Thi Thao Dang, (2017). Teacher Readiness for Online Teaching: A Critical Review. IJODeL (Journal), 3(1), 1-15. Google Scholar $x^{\prime}$ CrossRef/DOI $x^{7}$ 
[29] Ming-Hung Lin, Huang-Cheng Chen, Kuang-Sheng Liu, (2017). A Study of the Effects of Digital Learning on Learning Motivation and Learning Outcome. Journal of Mathematics Science and Technology Education, 13(7), 3553-3564.

Google Scholar ${ }^{\top} \quad$ CrossRef/DOI $\chi^{\top}$

[30] Mansureh Kebritchi, Angie Lipschuetz, Lilia Santiague, (2017). Issues and Challenges for Teaching Successful Online Courses in Higher Education: A Literature Review. Journal of Educational Technology Systems, 46(1), 4-29.

Google Scholar $x^{7} \quad$ CrossRef/DOI $x^{\nearrow}$

[31] Wingo, Nancy Pope; Ivankova, Nataliya V.; Moss, Jacqueline A., 2017. Online Learning. Education and Information Technology, 21(1), 15-35.

Google Scholar $X^{\top} \quad$ CrossRef/DOI $X^{\top}$

[32] Devendra Bhongade, Yogesh M. Sarode, 2018. Prospect of E-learning in Indian Education: Trends and Issues, International journal of current engineering and scientific Research (IJCESR), 5(5), 180-186.

Google Scholar $\chi^{\top} \quad \underline{\text { CrossRef/DOIX' }}$

[33] Aman Jindal, Chahal, B. P. S. (2018). Challenges and Opportunities for Online Education in India. Pramana Research Journal, 8(4), 99-105.

Google Scholar $\nearrow^{\top} \quad$ CrossRef/DOI $\chi^{\top}$

[34] Taylor \& Francis, (2018). Comparing the Effectiveness of Classroom and Online Learning: Teaching Research Methods. Journal of Public Affairs Education, 19(2), 199-215. Google Scholar ${ }^{7} \quad \underline{\text { CrossRef/DOI }}$

[35] Martin, Florence; Budhrani, Kiran; Kumar, Swapna; Ritzhaupt, Albert, (2019). Award-Winning Faculty Online Teaching Practices: Roles and Competencies. Online Learning, 23(1), 184-205.

Google Scholar X CrossRef/DOIX

[36] Aithal, P. S. \& Aithal, Shubhrajyotsna (2019). Analysis of Higher Education in Indian National Education Policy Proposal 2019 and its Implementation Challenges. International Journal of Applied Engineering and Management Letters (IJAEML), 3(2), 1-30. Google Scholar $x^{7}$

CrossRef/DOIX

[37] Chrysi Rapanta \& Luca Botturi \& Peter Goodyear \& Lourdes Guàrdia \& Marguerite Koole, (2020). Online University Teaching During and After the Covid-19 Crisis: Refocusing Teacher Presence and Learning Activity. Post-digital Science and Education, 4(3), 923-945.

\section{Google Scholar $\nearrow^{\top} \quad$ CrossRef/DOI $x^{\top}$}

[38] Abhinandan Kulal and Anupama Nayak, (2020). A study on perception of teachers and students toward online classes in Dakshina Kannada and Udupi District. Asia Association of open universities Journal, 15(3), 285-296.

Google Scholar $x^{7} \quad$ CrossRef/DOI $x^{7}$

[39] Shivangi Dhawan, (2020). Online Learning: A Panacea in the time of COVID-19 Crisis. Journal of Educational Technology Systems, 49(1), 285-196.

Google Scholar $x^{7} \quad$ CrossRef/DOI 7

[40] Ethel Reyes-Chua, Brandon G. Sibbaluca, Rebecca D. Miranda, Georgina B. Palmario, Ramil P. Moreno, John Paul T. Solon, (2020). The Status of the Implementation of the E-Learning Classroom in Selected Higher Education Institutions in Region IV-A Amidst the Covid-19 Crisis. Journal of critical review, 7(11), 253-258.

Google Scholar X

CrossRef/DOIX

[41] Richard Watson Todd, (2020). Teachers' Perceptions of the Shift from the Classroom to Online Teaching. International Journal of TESOL Studies, 2(2), 4-16.

Google Scholar $\chi^{\top} \quad$ CrossRef/DOI $\chi^{\top}$

[42] Brittany Lippincott and Nishant Hyanki, (2020). Overview of online education in India. SANNAM $S 4,12(2), 53-61$.

Google Scholar X $\quad \underline{\text { CrossRef/DOIX }}$

Hegde Lata Narayan, et al, (2021); www.srinivaspublication.com 
[43] Panda, S. (2020). A study on the effectiveness of online teaching in pharmacy education from teacher and student perspectives during the COVID-19 pandemic. Pharmacyeducation.fip.org, 20(2), 20-25.

Google Scholar $x^{\top}$

\section{CrossRef/DOIX}

[44] Athira B, (2020). A mixed-method approach to evaluate the effectiveness of blended learning using clinical research modules in Pharmacy students. Research papers shodhganga@Inflibnet. 20(2), 361-368.

Google Scholar X

\section{CrossRef/DOI $x^{7}$}

[45] Aithal, P. S. \& Aithal, Shubhrajyotsna. (2020). Conceptual Analysis on Higher Education Strategies for Various Tech-Generations. International Journal of Management, Technology, and Social Sciences (IJMTS), 5(1), 11-22.

Google Scholar X $\quad$ CrossRef/DOI $\chi^{\nearrow}$

[46] Sumitra Pokhrel and Roshan Chhetri, (2021). A Literature Review on Impact of COVID-19 Pandemic on Teaching and Learning, Higher Education for the future, 8(1), 133-141.

Google Scholar ${ }^{7} \quad$ CrossRef/DOI $x^{7}$

[47] Muthuprasada S., Aiswaryab K. S, Adityaa Girish K. Jhaa, (2021). Students' perception and preference for online education in India during COVID -19 pandemic. Social sciences \& Humanities open, 3(1), 180-186.

Google Scholar $x^{\top} \quad$ CrossRef/DOI ${ }^{\top}$

[48] Roma Singh, ShrutiTiwari, (2021). Online Learning as Future Transition of Education in Indian Prospect. Journal of Engineering \& Technology, 7(1), 63-72.

Google Scholar $x^{7} \quad$ CrossRef/DOIX

[49] Michael Agyemang Adarkwah, (2021). "I'm not against online teaching, but what about us?" ICT in Ghana post Covid-19. Education and Information Technologies, 1(1), 1-21. Google Scholar $X^{\nearrow} \quad$ CrossRef/DOI $x^{7}$

[50] Shabnam Gurung, (2021). Challenges Faced by Teachers in Online Teaching during Covid19 Pandemic. The Online Journal of Distance Education and e-Learning, 9(1), 8-18. Google Scholar $x^{\top} \quad$ CrossRef/DOI $x^{\top}$

[51] Aithal, P. S., \& Aithal, S. (2015). An innovative education model to realize ideal education system. International Journal of scientific research and management (IJSRM), 3(3), 2464-2469. Google ScholarX

[52] Aithal, P. S., \& Kumar, P. M. (2015). Applying SWOC analysis to an institution of higher education. International Journal of Management, IT and Engineering, 5(7), 231-247.

Google Scholar ${ }^{\top}$

$* * * * * * * * *$ 